\title{
Problems and methods of numerical and experimental investigation of high rise constructions' aerodynamics in the coastal region «sea-land»
}

\author{
S.A. Isaev* \\ N.I. Vatin, \\ Saint-Petersburg State Polytechnical University \\ V.A. Lebiga, \\ V.N. Zinoviev, \\ Khistianovitch Institute of Theoretical and Applied Mechanics SB RAS \\ Keh-Chin Chang, \\ Jiun-Jih Miau, \\ National Cheng Kung University
}

Key words: high buildings; wind influence; unsteady flow; forces; pulsation; calculation; verification; multiblock grids; models of turbulence; URANS; program package; hot-wire technique; PIV technique; Wavelet-analysis

\section{Introduction}

Study of unsteady atmospheric flows around irregular obstacles with regard to the specificity of the relief presents an important basic problem of aerodynamics.

This paper is directed to consider several interrelated problems: predictions and measurements of unsteady wind loads at high rise buildings and urban development with regard to discrete roughness, vegetation and wood, and relief in the coastal region "sea-land"; computation of vibrations of high rise constructions as acted upon by sign-variable wind loads; determination of a rational location of building structures on the relief in terms of the criterion of minimal drag to the wind action; ecological monitoring of the relief; investigation of averaged characteristics and pulsation characteristics of the flow near an isolated body, tandem and a pack of bodies.

\section{State of the problem. Review of methods and results}

The problem of this paper is related to one of the perspective directions of building aerodynamics study of unsteady separated wind flow around constructions bound up with the vortex dynamics at the presence of a discrete roughness, vegetation and forests and the relief in the coastal area. At a new stage of developing numerical simulation method with the use of semi-empirical and static turbulence model, it is urgent to solve the problem of controlling flow over an urban area stood with high rise buildings with regard to discrete roughness of the relief in the coastal area "sea-land".

Systematic numerical investigations that were made during the last several years rest upon the many years' experience in numerical simulation, the most important priority results being obtained in the following fields:

a) designing and analysis of factorized algorithms using multiblock technologies for computation of separated flows of inhomogenous liquid and heat transfer;

b) solution of complex tasks of control of separated flows by organizing large-scale vortex structures, including in the case of selecting nontraditional aerodynamic shapes of blunt bodies with the intent to reduce drag and to enhance heat and mass transfer processes;

c) numerical study of the effect of geometric and working parameters on the separated flow structure, identification of jet-vortex structures in 3D separated flows, interpretation of unsteady periodic $2 \mathrm{D}$ and $3 \mathrm{D}$ vortex formation processes, development of original procedures of computing periodic flows and heat transfer in space coordinates, creation of high-efficient computational codes (VP2/3 - velocitypressure, 2D/3D) for numerical simulation on personal computers and multiprocessor clusters with an accuracy sufficient for engineering practice.

There is nearly forty-year experience in multi-dimensional numerical simulation of vortex and separated flows, including those in the annex to the aerodynamics of bluff bodies with vortex generators. The experience is summarized in the series of monographs [1-3]. Priority is given to the development, validation and application of turbulence models for solving problems of unsteady aerodynamics [4, 5]. Of particular note is the analysis of drag reduction models of high-rise buildings based on the throttling effect [6].

Исаев С.А., Ватин Н.И., Лебига В.А., Зиновьев В.Н., Кэ-Чин Чан, Цзюн-Цзи Мяу. Задачи и методы численного и физического исследования аэродинамики высотных зданий в прибрежной зоне «море-суша» 
The development of mesoscale mathematical models which are taking into account the influence of terrain orography on the formation of surface wind flow interacting with an ensemble of high-rise buildings is one of the most important solvable problems of this paper. So far, this trend was developed in the framework of themes related to the prediction of hazardous wind shear in the neighborhood of airports during take-off and landing of an aircraft $[7,8]$. Mainly, the considered subject matter is combined with the current trend in thermal physics, dedicated to the vortex intensification of heat transfer in the flow over the surface with holes and protrusions, where a considerable experience is also obtained in the analysis of the jet-vortex mechanism control [9].

During almost ten years the direction of the numerical simulation of ventilation tunnels and underground structures has gradually grown into the problems of building aerodynamics. Moreover, it should be noted that a recent study conducted in collaboration with experimentalists at the Institute of Mechanics of Moscow State University (Figure 1) [10,11] can be considered as an important step of the development of numerical studies based on the use of different scales overlapping grids multiblock computational technologies and package VP2 / 3, which in its quality is not inferior to such universal packages like "Fluent" and CFX [12].

a)

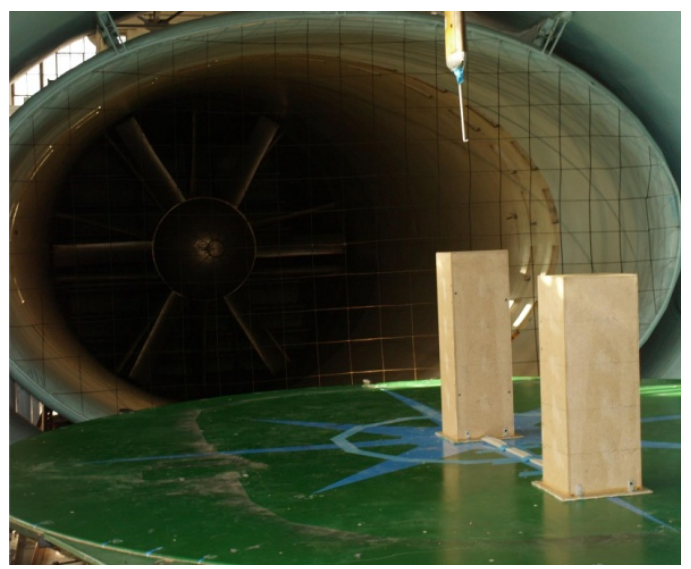

Figure 1. Model of building ensemble in a wind tunnel (a), failure of a vortical veil at a flow of a tandem of buildings (b) and comparison settlement and experimental $C p$ on the back side of the second building (c) b)

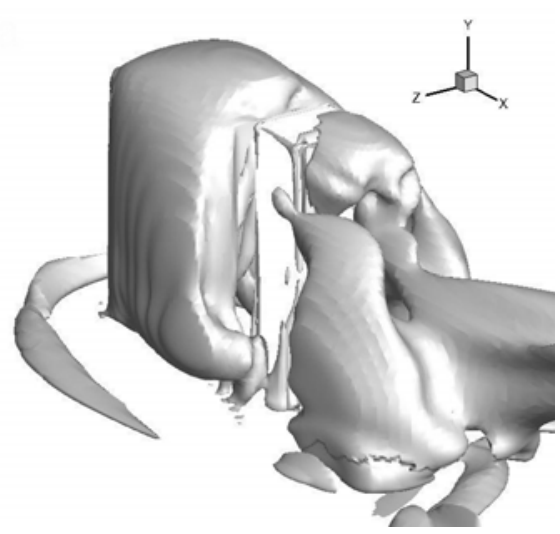

c)

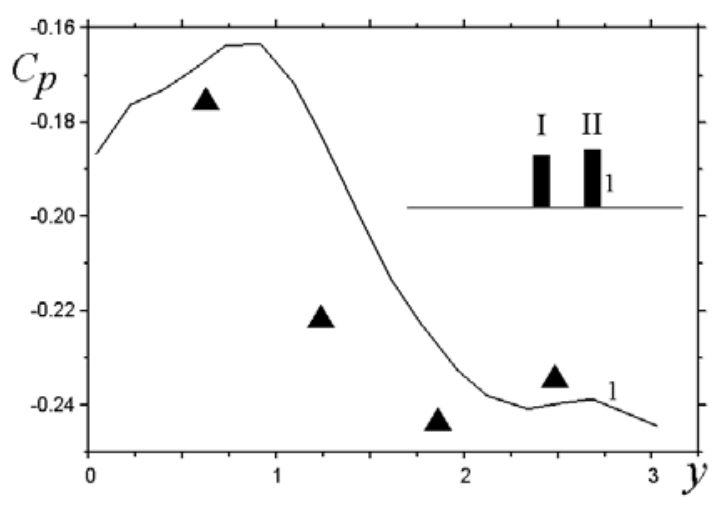

There is the extensive experience in designing, creating and using hot-wire equipment for measuring of average and fluctuation characteristics of flow over a wide speed range at the ITAM SB RAS [13]. It is known that hot wire is the most appropriate tool for measuring fluctuations in the flow of gas and liquid. The ITAM group has also performed a number of studies and obtained new results, which allowed essentially developing a technique to measure fluctuations in the compressible and incompressible flows. An original universal method of determining the coefficients of hot-wire probe sensitivity was developed [13]. The method of fluctuation diagrams used in the ITAM can not only determine the velocity fluctuations, but also density, temperature and pressure. The method of fluctuation diagrams proposed by Kovazhnay for supersonic flow was developed by the ITAM group and made as the available one for subsonic flows. In particular, it was shown that the output signal of the hot-wire probe corresponding to acoustic-type fluctuations depends not only on the intensity of these fluctuations, but also on their orientation in the flow and the relative position of the probe and the fluctuation source [13]. Analysis was made for localized sources of acoustic fluctuations and acoustic fluctuations of equal intensity, evenly distributed on the surface or in the flow. With using of the obtained results, methodical measurements of fluctuations in test sections of different wind tunnels were carried out, including the transonic wind tunnel TWT at NCKU. 
A number of researches on the flow around cylinders of different configurations streamlined with subsonic flow in the range of Reynolds numbers were made at the National Cheng-Kung University, including critical Reynolds numbers up to 600,000 . Studies of the flow structure around circular, rectangular and trapezoidal cylinders were made with detailed measurements of the fluctuations in the vicinity of the cylinder using the surface film sensors, while velocity fluctuations in the cylinder wake using usual hot wire probes. The measurements were performed by means of an array of MEMS-sensors located on the surface of the cylinder. The measured data were processed with wavelet transformation, which was developed in DAA group of Taiwan, to investigate the characteristics of unsteady flow separation and propagation of the vortices.

Both intrusive and non-intrusive measurements will be performed in this research to verify the capability and uncertainty of these measurement techniques in the wake flow. Hot-wire and split-fiber film probes will be applied in the developments of the intrusive techniques, while the PIV measurements will be performed as the non-intrusive technique to make comparison and verification of the data. The working principles of these measurement techniques are quite different. Sometimes the PIV technique is used to measure the velocity field of the wake flows. However, the accurate measurements using PIV technique depend on the treatments of the seeding particles in the wake. It is necessary to control the quantity, density and uniformity of the seeding particles to avoid the particle collisions in the wake what can be a reason of measurements distortion. Furthermore, it is supposed to perform the measurements of the high rise structure in the ABRI meteorological tunnel with using PIV technique. However, it is quite difficult due to insufficient laser power and too small field of the view (FOV) of the camera lens, because the ABRI meteorological tunnel has a large test section with dimensions of $4 \mathrm{~m}$ in width and $2.6 \mathrm{~m}$ in height.

In contrast, the measurements with hot-wire and split-fiber film probes are performed without aforementioned difficulty. In this research, the measuring scheme of hot-wire and split-fiber film probes can be verified through the comparision with the PIV data in the wake behind a long cylinder (twodimensional flow). There are three particular regions of the flow characteristics in the wake, including the free stream region, the mixing layer region and the recirculation flow region. The data of the hot-wire measurements in the free stream and mixing layer are correct enough for the bench mark data as comparing to those measured by split-fiber film probes and PIV techniques. However, the split-fiber film probe is capable of distinguishing positive/negative velocity in the recirculation zone of the wake. Hence, the technique of the split-fiber film probes can be used in the ABRI meteorological tunnel as a part of measuring scheme and its using ought to be confirmed both by the hot-wire measurements outside the recirculation flow and by PIV measurements inside the recirculation zone.

The experiments of the wake behind a long cylinder should be firstly performed in the facility of a small blow down wind tunnel with horizontal test section including the settling chamber, contraction section, and noise reduction chamber. The size of the test-section of the wind tunnel is $40 \mathrm{~mm} \times 40 \mathrm{~mm}$. The size of the cylinder will be selected as the Reynolds number of the wake flow is corresponding to the Reynolds number of the flow in the coastal zone.

The PIV system consists of a pulsed diode laser, a high speed camera with a $50 \mathrm{~mm}$ Nikon standard lens, a synchronizing timing hub, and a personal computer for data acquisition. The wavelength of the diode laser is $795 \mathrm{~nm}$ and the maximum pulse power is $10 \mathrm{~W}$. The camera frame rate for capturing digital images is 2565 frames/s with full resolution of $512 \times 512$ pixel $^{2}$. The illumination is made with a pulse separation period of $60 \mu \mathrm{s}$. Each data of turbulent flow properties is analyzed using 2200 frames. Based on these experimental conditions, the maximum tracer displacement $\left(\Delta \mathrm{x}_{\mathrm{m}}\right)$ is estimated to be four pixels between the two sequential frames, which is equivalent to $0.125 \mathrm{~mm} / \mathrm{pixel}$ of the camera spatial resolution. Seeding tracers with the nominal size of $2 \mu \mathrm{m}$ are generated by a Laskin nozzle (using olive oil as the working fluid).

Poor illumination of the PIV measurement stemming from non-uniform tracer distribution particularly in wake results in blurred images with less brightness and low contrast. It requires the spatial filtering implementation to sharpen the blurred edge of an image. There are generally three spatial filters, including Laplacian, Prewitt and Sobel filters. Among them, Prewitt and Sobel filters are suitable to perform unitary sharpening which can fit the flow condition with anisotropic velocity gradients such as occurred in shear layer. Since high dynamic range of gray level is required for the accurate crosscorrelation calculations in PIV measurement, an image post-processing who combined the gray level transfer function for contrast enhancement and the spatial sharpening is employed for the PIV measurement in the wake.

Исаев С.А., Ватин Н.И., Лебига В.А., Зиновьев В.Н., Кэ-Чин Чан, Цзюн-Цзи Мяу. Задачи и методы численного и физического исследования аэродинамики высотных зданий в прибрежной зоне «море-суша» 
The measurement techniques include the following topics:

a) quantitative analysis of the instantaneous behaviors of vortex shedding behind two or threedimensional bluff bodies [13-16];

b) non-stationary characteristics of vortex shedding of bluff bodies at critical Reynolds numbers $[17,18]$;

c) intrusive measurement of instantaneous positive/negative velocity with high time resolution $[19,20]$

d) quantitative measurement of the instantaneous behaviors of turbulent flow by means of PIV diagnostics [21-23].

\section{Possible methods and approaches to solving the stated tasks}

The work can be executed mainly by numerical simulation methods with a wide use of multiparameter physical experiment.

To solve 2D and 3D problems for the wind action upon a building structure, there will be made the mathematical models based on the system of unsteady Reynolds number averaged Navier-Stokes (URANS) equations for turbulent flow and the energy equation (when compressibility is to be taken into account and the equations of continuity and state are added). The governing system of equations is closed with the differential equations of the chosen semi-empirical turbulence model. The considered problems are proposed to use the low Reynolds number versions of the zonal model of Menter's shear stress transfer [24, 25] modified with regard to the influence of curvature of streamlines on turbulence characteristics within the framework of the approaches of Leshtsiner-Rodi-Isaev [3] and Smirnov-Menter [26] for computation of vortex viscosity. Low Reynolds number versions of the zonal model of Menter's shear stress transfer is replaced by the deformation velocity module (Menter's model 2003) [27, 28]. The Spalart-Allmares one-parameter model of vortex viscosity with correction for Spalart-Shur rotation is used [29]. An additional semi-empirical constant in the correcting linear dependence on the turbulent Richardson number is determined from many numerical experiments (when solving the problems of liquid circulation motion in a square cavity and of flow around a disc and a system of discs; execution of a comparative analysis of numerical results with experimental data of Mailz, Karmodi, Morel and Bon, Roshko and Kenig, with the results obtained by the algebraic Reynolds stress model proposed by Rodi) and for Menter's model it is taken equal to 0.02 [3]. In addition to URANS, consideration is made of the model of comparative scales of SAS-MSST in Davidson's interpretation [30]. Also, for comparison it is planned to use the model of large eddy simulation and detached eddy simulation (LES/DES) [31].

The system of the governing equations is written in delta-form in the curvilinear coordinates connected with the computational domain boundaries relative to the increments of dependent variables including Cartesian velocity components. Upon linearization, the system of the governing equations is solved by the finite-volume procedure of SIMPLEC type based on the concept of splitting into physical processes $[32,33]$. In this case, the E-factor scheme is used to decrease the influence of numerical diffusion in computations of flows with organized flow separation, which are very sensitive to approximation errors of the convective terms, the explicit part of the transport equations uses Leonard's square upwind scheme [34]. Discretization of the convective terms of the transport equations of turbulence characteristics and the energy equation is made according to the UMIST scheme representing a version of the TVD scheme for incompressible flows [35] and according to Van Leer's scheme for compressible flows [36].

Computations of different-scale flows are made on multiblock multilevel grids with their mutual overlapping. An original procedure of parameter interpolation is constructed at coinciding meshes with a different-grid structure that provides proper conservatism in solving the stated problems. The developed factorized algorithm is extended to the case of multiblock computational grids within the framework of the concept of decomposition of the computational domain and of generation of oblique $\mathrm{H}$ - and $\mathrm{O}$-type meshes with overlapping in the distinguished different-scale subregions. Values between overlapping meshes are transported according to the multiblock grid strategy with the use of non-conservative linear interpolation. The equivalence of the proposed method and the known method of conservative interpolation is proved. To design curvilinear meshes coinciding with the boundaries, approved computation algorithms of algebraic and elliptical type are used [37].

A specialized multiprofile code VP2/3 is designed using the multiblock computational technologies (MCT). Its parallel version is meant for computations on cluster multiprocessor systems and, first of all, for computations of unsteady processes in $3 \mathrm{D}$ separated flows. Testing showed that this approach is similar to the use of adaptive non-structured grids, but it needs much less computational resources and processor time. In the main, the high computational efficiency of MCT in comparison with traditional

Исаев С.А., Ватин Н.И., Лебига В.А., Зиновьев В.Н., Кэ-Чин Чан, Цзюн-Цзи Мяу. Задачи и методы численного и физического исследования аэродинамики высотных зданий в прибрежной зоне «море-суша» 
approaches is determined by an essential decrease in the used grid resources, since "superfluous" mesh nodes specific for monoblock grids with the crowding of lines are cancelled, as well as mesh steps change non-monotonically. It should be noted also that the VP2/3 code contains computation modifications of wall flows when combining the turbulence low Reynolds number models and the wall functions. In addition, instead of widely used inlet boundary conditions, as which one usually uses velocity profiles taken from experiments or the theory of integral relations, the approach based on the iteration parabolized procedure is approved. This approach does not practically introduce disturbances into the solving of the problem in the vicinity of the inlet boundary of the computational domain and allows one to make it essentially closer to the considered vortex generator. Following Menter, it is proposed to compute a distance to the nearest wall on the basis of solving a special equation of Poisson type. This approach permits one to make the determination of the important characteristic easier in solving the low Reynolds number equations for turbulence models in the case of the multiply bounded regions of complex geometry.

The specificity of the investigation is the complexity of study, namely, the execution of numerical simulation of flows corresponding to experiments in wind tunnels. In what follows, one will make mutual verification and add computation results to the data of many-parameter physical experiment aimed at determining the influence of geometric and working parameters on characteristics of wind loads both at a single obstacle and a group of obstacles of different geometry with regard to the disturbing action of discrete roughness and elements of the relief.

The experimental part of investigations is to visualize flows in the vicinity of bluff bodies and to measure aerodynamic drag, averaged and fluctuation characteristics in the wake behind them. Experiments will be made in wind tunnels at ITAM SB RAS and in the meteorological wind tunnel of ABRI. To make the preliminary experiments and to make the equipment ready, it is planned to use wind tunnel T-325M at ITAM. Experiments will use cylindrical and rectangular models, both isolated and arranged in a package. Information on the development of flow disturbances will be obtained with the use of hot-wire measurements. In order to do this, software-controlled hot-wire complexes operating on the constant current and constant temperature principles, as well as Kulite pressure transducers with a frequency range up to $200 \mathrm{kHz}$ will be used. In addition to the traditional single-wire probes, it is planned to use split-fiber film probes, DANTEC 55R55, to detect the recirculating motion within the wakes behind the constructions because of its potential capability for simultaneously measurement both the flow direction and high-frequency velocity fluctuations. A nonintrusive method of measuring the velocity distribution, which does not disturb the flow and is capable of distinguishing flow direction, namely, particle image velocimetry (PIV), will also be used to validate the measurements made with split-fiber film anemometry, particularly in the recirculating flow regions. To investigate the unsteady and nonlinear processes it is proposed to use the method of the Wavelet analysis and higher statistical moments for processing computation results and experimental data. These methods have undoubted advantages since they provide a basis for obtaining a full spatial-temporal characteristics of the phenomenon.

\section{Some details of the study and expected results}

The first part:

- classification of typical constructions and making a catalogue of tasks of architecture-building aerodynamics on the basis of combining different-type structures with typical discrete roughness (hills and valleys) and meso-scale elements of the relief;

- formulation of the problem of vibrations of a high rise building under wind loads;

- development and testing of algorithms and software (in $\mathrm{C}++$ ) using MCT oriented to many computations within the framework of URANS and SAS as applied to clusters;

- designing, manufacturing and testing of models of physical experiment in the wind tunnel T325M at ITPM SB RAS for measurements of averaged and fluctuation characteristics in the wake behind bluff bodies;

- development and ready for measurement methods capable of distinguishing instantaneous positive / negative velocities and their fluctuation components with using the hot wire and film probes in the wake behind a long cylinder (2D flow);

- writing and approving software for control of hot-wire measuring complexes and for experimental data acquisition and processing during experiment, as well as formation of the database;

- designing, manufacturing and testing of the model (long cylinder, 2D flow) for the experiments in the small-scale low-speed wind tunnel of DAA;

- development and the ready for measurement method capable of distinguishing instantaneous positive/negative velocities with high time resolution by use of split-fiber film probe;

Исаев С.А., Ватин Н.И., Лебига В.А., Зиновьев В.Н., Кэ-Чин Чан, Цзюн-Цзи Мяу. Задачи и методы численного и физического исследования аэродинамики высотных зданий в прибрежной зоне «море-суша» 
- development and the ready for measurement method using the PIV method for quantitative measurement of turbulent flow in the wake behind a long cylinder (2D flow) with the intent to determine an instantaneous velocity field;

- problem formulation and the ready for the numerical simulation of turbulent flow across a long, horizontal cylinder by using available URANS models.

The second part:

- designing and testing of matched boundary conditions for velocity components and turbulence characteristics in solving problems of interaction of the 3D wind flow with different-roughness distributed elements;

- numerical simulation of the vegetation influence on the development of a non-uniform wind flow, and estimation of its influence on aerodynamic unsteady loads at constructions;

- consideration of the test example of vibrations of a high rise building under the wind action;

- conducting physical experiment on the load measurement at a bluff body with discrete roughness elements and averaged and fluctuation characteristics in the wake behind it;

- physical experiments in order to study vibrations of a high rise construction models under aerodynamic forces;

- performance of the experiment of the flow over a long cylinder (2D flow) in the wind tunnel T$325 \mathrm{M}$ at ITAM by means of the developed hot wire method;

- performance of the experiment of the flow over a cylinder (2D flow) in the small-scale low-speed wind tunnel at DAA by means of the developed split-fiber film and PIV methods, respectively;

- comparison of the measurement data obtained with local instrumental technique (split-fiber film probe) and with nonintrusive technique (PIV);

- numerical simulation of the flow cases tested in the wind tunnel experiments (both in Taiwanese and Russian Part);

- validation of the developed split-fiber film method and hot wire method (in Russian Part) through comparing their measured data with the corresponding numerical predictions;

- designing, manufacturing and testing of models to be tested in the ABRI meteorological tunnel in order to investigate wind loads at various layout of constructions under disturbances located upstream.

The third part:

- statement of the task of a wind flow formation in the coastal area "sea-land" and the development of factorized algorithms and software for solution of the tasks stated above;

- ecological monitoring of the relief with the urban area, including in the coastal zone;

- analysis of procedures of drag reduction of high rise constructions (formation of ensembles, use of the throttling effect, and determination of a rational location of buildings on the relief through the criterion of minimal drag to the wind action;

- performing the experiments in the ABRI meteorological tunnel, associated with tandems and ensembles of high rise construction models in view of discrete roughness and relief with the intent, to reduce the drag of constructions and to find their rational location on the relief;

- comparison of experimental results with numerical simulation data.

After the investigation has been executed, it is planned to obtain theoretical and applied outcome.

\section{Theoretical outcome}

1. Methodical developments for computation of the wind action upon a high rise construction and the urban area in view of discrete roughness, vegetation and relief.

2. Comparison of the numerical simulation estimates of the wind action upon constructions investigated in the meteorological tunnel and of the wind flow in the coastal area "sea-land".

3 . Ecological monitoring of the relief and the urban development, including in the coastal area.

4. Development, approbation, and verification of the grid - gridless method for numerical simulation of disturbance transfer at large distances in an effort to refine the computation of a far wake at wind loading of constructions.

5. Comparison of numerical predictions of the wind action upon high rise constructions in the framework of URANS, SAS-URANS and DES.

6. Results of the analysis of the acceptability of the town-planning concept based on minimizing the force wind action upon building constructions with reference to the relief.

7. Development of factorized algorithms and software (in $\mathrm{C}++$ ) using the multi-block computational technologies realized in the modified code VP2/3 for solution of the stated problems of architecturebuilding aerodynamics with regard to the coincidence of inlet boundary conditions and rough wall 
conditions; development of the parallel code version means for numerous computations within the framework of URANS, SAS and DES as applied to multiprocessor, cluster systems.

\section{Applied outcome}

1. Development of measurement techniques to be suitable for investigation of turbulent flow fields which are associated with instantaneous positive / negative velocities and high frequency fluctuations.

2. Validation of the proposed approach of multi-block computational technology through comparisons of the numerical predictions with the database obtained with using of the intrusive techniques including hot wire and split-fiber film probes.

3. Results of the analysis for drag reduction of high rise constructions under various wind loads (formation of ensembles, use of the throttling effect)

4. Recommendations on drag reduction of combined constructions and ensembles to substantiate a perspective town-planning concept.

The authors acknowledge gratefully the support of the Russian Foundation for Basic Research (Projects 11-01-00039).

\section{References}

1. Белов И.А., Исаев С.А., Коробков В.А. Задачи и методы расчета отрывных течений несжимаемой жидкости. Л.: Судостроение, 1989. 256 с.

2. Управление обтеканием тел с вихревыми ячейками в приложении к летательным аппаратам интегральной компоновки (численное и физическое моделирование) / Под ред. А.В. Ермишина и С.А. Исаева. М.: МГУ, 2003. 360 с.

3. Быстров Ю.А., Исаев С.А., Кудрявцев Н.А., Леонтьев А.И. Численное моделирование вихревой интенсификации теплообмена в пакетах труб. СПб.: Судостроение, 2005. 398 с.

4. Белов И.А., Исаев С.А. Моделирование турбулентных течений. Учебное пособие. СПб.: БГТУ, 2001. $107 \mathrm{c}$.

5. Isaev S.A., Baranov P.A., Kudryavtsev N.A., Lysenko D.A., Usachov A.E. Comparative analysis of code packages VP2/3 and FLUENT in the calculation of unsteady flow around a circular cylinder with turbulence models of Spalart Allmares and Menter // Journal of Engineering Physics. 2005. Vol.78. No. 6. Pp. 148162.

6. Isaev S.A., Zhdanov V.L., Niemann H.-J. Numerical study of the bleeding effect on the aerodynamic characteristics of a circular cylinder // Journal of Wind Engineering and Industrial Aerodynamics. 2002. Vol. 90. Issue 11. Pp. 1217-1226.

7. Isaev S.A., Belousova L.Yu., Baranov P.A. Numerical analysis of the wind regime in the neighborhood of Pulkovo airport // J. Engineering Physics and Thermophysics. 1999. Vol.72. No.4. Pp. 644-649.

8. Бабаскин В.В., Исаев С.А., Метов Х.Т., Чепига В.Е. Моделирование и система предупреждения опасного орографического сдвига ветра в аэропортах // Полет. 2008. №12. С. 27-34.

9. Isaev S.A., Kornev N.V., Leontiev A.I., Hassel E. Influence of the Reynolds number and the spherical dimple depth on the turbulent heat transfer and hydraulic loss in a narrow channel // International Journal of Heat Mass Transfer. 2010. Vol.53. Issues 1-3. Pp. 178-197.

10. Baranov P.A., Golikov A.D., Isaev S.A., Makhviladze G.M., Snegirev A.Yu. Numerical and physical modeling of fire development and smoke movement in a subway hall // Proceedings of the Third International Seminar on Fire and Explosion Hazards, 10 - 14 April 2000. Windermere, Lake District, UK, 2001. Pp. 745-757.

11. Гувернюк С.В., Егорычев О.О., Исаев С.А., Корнев Н.В., Поддаева О.И. Численное и фризическое моделирование ветрового воздействия на группу высотных зданий // Вестник МГСУ. 2011. Т. 1. №3. C. $185-191$.

12. Исаев С.А., Судаков А.Г., Баранов П.А., Усачов А.Е., Стрижак С.В., Лоханский Я.К., Гувернюк С.В. Разработка, верификация и применение основанного на многоблочных вычислительных технологиях распараллеленного пакета открытого типа VP2/3 для решения фрундаментальных, прикладных и эксплуатационных задач аэромеханики и теплофизики // Вестник ЮУрГУ. Серия «Математическое моделирование и программирование». 2009. №17(150). Вып.3. С. 59-72.

13. Zinoviev V.N., Lebiga V.A., Pak A.Yu. Hardware and software for hot-wire measurements of unsteady flows // NSC - RFBR Joint Sympos. "Study of Unsteady Processes in Problems of Continuum Mechanics by New Approaches to Physical and Numerical Modeling", 16-17 April, Tainan, Taiwan, 2009.

14. Miau J.J., Wang J.T., Chou J.H., Wei C.Y. Low-frequency fluctuations in the near-wake region of a trapezoidal cylinder with low aspect ratio // Journal of Fluids and Structures. 2003. Vol. 17. Pp. 701-715.

Исаев С.А., Ватин Н.И., Лебига В.А., Зиновьев В.Н., Кэ-Чин Чан, Цзюн-Цзи Мяу. Задачи и методы численного и физического исследования аэродинамики высотных зданий в прибрежной зоне «море-суша» 
15. Wu S.J., Miau J.J., Hu C.C., Chou J.H. On low-frequency modulations and three-dimensionality in vortex shedding behind a normal plate // Journal of Fluid Mechanics. 2005. Vol. 526. Pp. 117-146.

16. Zinoviev V.N., Lebiga V.A., Miau J.J., Chung K.M., Hu C.C., Tu J.K. Experimental investigation of flow fluctuations around the cylinder in subsonic flows with the help of Hilbert transform and the EMD technique // NSC - RFBR Joint Sympos. "Numerical and Experimental Modeling of Microprocesses and Its Application in Continuum Mechanics ", 28-30 November 2006, Tainan, Taiwan. Pp. IV-2.

17. Lin Y.J., Miau J.J., Tu J.K., Tsai H.W. Nonstationary, three-dimensional aspects of flow around circular cylinder at critical Reynolds numbers // AIAA Journal. 2011. Vol. 49. Pp. 1857-1870.

18. Miau J. J., Tsai H. W., Lin Y. J., Tu J. K., Fang C. H. and Chen M. Experiment on smooth circular cylinders in cross-flow in the critical Reynolds number regime // Experiments in Fluids. 2011. Vol. 51. Pp. 949-967.

19. Hasebe H., Watanabe K., Watanabe Y. and Nomura T. Experimental study on the flow field between two square cylinders in tandem arrangement // Proceedings of 7th Asian-Pacific Conference on Wind Engineering. Taipei, Taiwan. 2009. Pp. 631-634.

20. Chang T.C., Lin J.H., Chang K.C., Wang M.R. Investigation of velocity measurement in backward-facing step flow // Proceedings of 2011 Conference of Aeronautical and Astronautical Society of R.O.C. 2011. Paper No. 02-15.

21. Li C.T., Chang K.C., Wang M.R. PIV measurements of turbulent flow in planar mixing layer // Experimental Thermal and Fluid Science. 2009. Vol. 33. Pp. 527-537.

22. Li C.T., Chang K.C., Wang M.R. Experimental study on evolution of joint velocity PDF in planar mixing layer // Experimental Thermal and Fluid Science. 2010. Vol. 34. Pp. 1122-1132.

23. Miau J. J., Fang C.H., Chen C.M., Yang R.J., Fomin V., Lebiga V., Zinovyev V. Discrete transition of flow over a circular cylinder in the pre-critical regime // Taiwan-Russia Bilateral Symposium on Mechanical Engineering. Taiwan, Hsinchu. November 8-9, 2011. Abstract Book. Pp. 8.

24. Menter F.R. Zonal two equation k-w turbulence models for aerodynamic flows // AIAA. 1993. No.2906. Pp. 1-21.

25. Hellsten A. Some improvements in Menter's k- $\omega$ turbulence model // AIAA. 1998. No.98-2554. Pp. 1-11/

26. Smirnov P.E., Menter F. Sensitization of the SST turbulence model to rotation and curvature by applying the Spalart-Shur correction term // Proc. ASME Turbo Expo Conf., 2008. N GT2008-50480. 10 p.

27. Menter F.R., Kuntz M., Langtry R. Ten years of industrial experience with the SST turbulence model // Proceedings of the Fourth International Symposium on Turbulence, Heat and Mass Transfer, Antalya, Turkey, 12-17 October, 2003. Pp. 625-632.

28. Esch T., Menter F.R. Heat transfer predictions based on two-equation turbulence models with advanced wall treatment // Proceedings of the Fourth International Symposium on Turbulence, Heat and Mass Transfer, Antalya, Turkey, 12-17 October, 2003. Pp. 663-640.

29. Spalart P.R., Allmares S.R. A one-equation turbulence model for aerodynamic flows // AIAA Paper. 1992. №92-0439. 22 p.

30. Davidson L. Evaluation of the SST-SAS model: channel flow, asymmetric diffuser and axy-symmetric hill // Proceedings of European Conference on CFD / Eds. P. Wesseling, E. Onate and J. Periaux. TU Delft, The Netherlands. 2006. 20 p.

31. Tkachenko I., Kornev N., Jahnke S., Steffen G., Hassel E. Performances of LES and RANS models for simulation of complex flows in a coaxial jet mixer // Flow Turbulence Combust. 2007. Vol. 78. Pp. 111-127.

32. Van Doormaal J.P., Raithby G.D. Enhancement of the SIMPLE method for predicting incompressible fluid flow // Numerical Heat Transfer. 1984. Vol.7. No. 2. Pp. 147-163.

33. Ferziger J.H., Peric M. Computational methods for fluid dynamics. Berlin: Springer-Verlag, 1999. 389 p.

34. Leonard B.P. A stable and accurate convective modeling procedure based on quadratic upstream interpolation // Computer Methods in Applied Mechanics and Engineering. 1979. Vol.19. No.1. Pp. 59-98.

35. Lien F.S., Leschziner M.A. Approximation of turbulence convection in complex flows with a TVD-MUSCL scheme // Proceedings of 5th International Symposium "Refined flow modelling and turbulence measurements". Paris, 1993. Pp. 183-190.

36. Oosteriee C.W., Gaspar F.J., Washio T., Wienands R. Multigrid line smoothers for higher order upwind discretizations of convection-dominated problems // Journal of Computational Physics. 1998. No.1. Pp. 274-307.

37. Thompson J.F. Numerical solution of flow problems using body-fitted coordinate systems // Computational Fluid Dynamics. 1980. Vol. 1. Pp. 1-98.

*Сергей Александрович Исаев, Санкт-Петербург, Россия Тел. раб.: +7(812) 771-03-11; эл. почma: isaev3612@yandex.ru

() Исаев С.А., Ватин Н.И., Лебига В.А., Зиновьев В.H., Keh-Chin Chang, Jiun-Jih Miau, 2013

Исаев С.А., Ватин Н.И., Лебига В.А., Зиновьев В.Н., Кэ-Чин Чан, Цзюн-Цзи Мяу. Задачи и методы численного и физического исследования аэродинамики высотных зданий в прибрежной зоне «море-суша» 


\title{
Problems and methods of numerical and experimental investigation of high rise constructions' aerodynamics in the coastal region "sea-land"
}

\author{
S.A. Isaev; \\ N.I. Vatin, \\ Saint-Petersburg State Polytechnical University, Saint-Petersburg, Russia; \\ V.A. Lebiga; \\ V.N. Zinoviev, \\ Khistianovitch Institute of Theoretical and Applied Mechanics SB RAS, Novosibirsk, Russia; \\ Keh-Chin Chang; \\ Jiun-Jih Miau, \\ National Cheng Kung University, Tainan, Taiwan \\ +7(812) 771-03-11; e-mail: isaev3612@yandex.ru
}

\section{Key words}

high buildings; wind influence; unsteady flow; forces; pulsation; calculation; verification; multiblock grids; models of turbulence; URANS; program package; hot-wire technique; PIV technique; Waveletanalysis

\section{Abstract}

Problems and methods of numerical and experimental studies of wind flow in the surface layer in the coastal zone "sea-land" and its impact on the urban area with high-rise constructions in view of a discrete roughness terrain and its topography are discussed. Some environmental conditions associated with the transport and dispersion of contaminants are under consideration.

Among the problems to be solved, there are several interconnected tasks: prediction of unsteady wind loads on high-rise buildings in urban area taking into account discrete roughness (including forests and topography) in the coastal zone; rational arrangement of buildings in the city area on the basis of the minimum drag criterion; experimental study of mean and fluctuation characteristics in turbulent flow over isolated body, tandem and packages of bodies. Application of numerical simulation in the framework of multiblock computational technologies to make valid prediction of wind loads in urban area with high-rise buildings using an approach based on solving URANS equation system jointly with SAS-MSST models of turbulence can be used. The special attention is paid to development of the coordinated conditions on entrance border of calculating area on the basis of the solution of a three-dimensional task on evolution of atmospheric boundary layer on a rough surface.

Experimental study of turbulent characteristics in shear areas of a flow around building models is performed by means of the intrusive diagnostics which are capable of measuring instantaneous positive and negative velocities with high time resolution, including the hot-wire technique developed at ITAM SB RAS and by split-fiber film technique developed at Department of Astronautics and Aeronautics (DAA) of National Chen Kung University (NCKU). Accuracies of the employed intrusive diagnostics are examined by comparing with the data obtained with the non-intrusive PIV technique. At studying of non-stationary processes the application of methods of the Wavelet-analysis and empirical decomposition of fluctuations, developed in DAA on time-frequency modes with Hilbert transformation is employed.

\section{References}

1. Belov I.A., Isaev S.A., Korobkov V.A. Zadachi i metody rascheta otryvnykh techeniy neszhimayemoy zhidkosti [Objectives and methods of calculating of the separation in incompressible flows]. Leningrad: Sudostroyeniye, 1989. $256 \mathrm{p}$.

2. Upravleniye obtekaniyem tel $s$ vikhrevymi yacheykami $v$ prilozhenii $k$ letatelnym apparatam integralnoy komponovki (chislennoye i fizicheskoye modelirovaniye) Pod red.aktsiyey A.V. Yermishina i S.A. Isaeva [Control flow around bodies with vortex cells applied to the aircraft with the integrated layout (numerical and physical modeling) Edited by A.V. Ermishin and S.A. Isaev]. Moscow: MGU, 2003. 360 p.

3. Bystrov Yu.A., Isaev S.A., Kudryavtsev N.A., Leontyev A.I. Chislennoye modelirovaniye vikhrevoy intensifikatsii teploobmena $v$ paketakh trub [Numerical simulation of vortex intensification of heat exchange in tube packs]. Saint-Petersburg: Sudostroyeniye, 2005. 398 p.

Isaev S.A., Vatin N.I., Lebiga V.A., Zinoviev V.N., Keh-Chin Chang, Jiun-Jih Miau. Problems and methods of numerical and experimental investigation of high rise constructions' aerodynamics in the coastal region "sea-land" 
4. Belov I.A., Isaev S.A. Modelirovaniye turbulentnykh techeniy. Uchebnoye posobiye [Simulation of turbulent flows. Textbook]. Saint-Petersburg: BGTU, 2001. 107 p.

5. Isaev S.A., Baranov P.A., Kudryavtsev N.A., Lysenko D.A., Usachov A.E. Comparative analysis of code packages VP2/3 and FLUENT in the calculation of unsteady flow around a circular cylinder with turbulence models of Spalart Allmares and Menter. Journal of Engineering Physics. 2005. Vol. 78. No.6. Pp.148-162.

6. Isaev S.A., Zhdanov V.L., Niemann H.-J. Numerical study of the bleeding effect on the aerodynamic characteristics of a circular cylinder. J. Wind Eng. Ind. Aerodyn. 2002. Vol. 90. Issue 11. Pp. 1217-1226.

7. Isaev S.A., Belousova L.Yu., Baranov P.A. Numerical analysis of the wind regime in the neighborhood of Pulkovo airport. J. Engineering Physics and Thermophysics. 1999. Vol. 72. No.4. Pp. 644-649.

8. Babaskin V., Isaev S.A., Metov Kh.T., Chepiga V.E. Flight. 2008. No.12. Pp. 27-34.

9. Isaev S.A., Kornev N.V., Leontiev A.I., Hassel E. Influence of the Reynolds number and the spherical dimple depth on the turbulent heat transfer and hydraulic loss in a narrow channel. Int. J. Heat Mass Transfer. 2010. Vol. 53. Issues 1-3. Pp. 178-197.

10. Baranov P.A., Golikov A.D., Isaev S.A., Makhviladze G.M., Snegirev A.Yu. Numerical and physical modeling of fire development and smoke movement in a subway hall. Proceedings of the Third International Seminar on Fire and Explosion Hazards, 10 - 14 April 2000. Windermere, Lake District, UK, 2001. Pp. 745-757.

11. Guvernyuk S.V., Egorychev O.O., Isaev S.A., Kornev N.V., Poddaeva O.I. Vestnik MGSU. 2011. Vol. 1. No.3. Pp.185-191.

12. Isaev S.A., Sudakov A.G., Baranov P.A., Usachov A.E., Strizhak S.V., Lohansky Y.K., Guvernyuk S.V. Vestnik YuUrGU. Seriya "Matematicheskoye modelirovaniye i programmirovaniye". 2009. Vol. 3. No.17(150). Pp. 59-72.

13. Zinoviev V.N., Lebiga V.A., Pak A.Yu. Hardware and software for hot-wire measurements of unsteady flows. NSC - RFBR Joint Sympos. "Study of Unsteady Processes in Problems of Continuum Mechanics by New Approaches to Physical and Numerical Modeling", 16-17 April, Tainan, Taiwan, 2009.

14. Miau J. J., Wang J. T., Chou J. H. and Wei C. Y. Low-frequency fluctuations in the near-wake region of a trapezoidal cylinder with low aspect ratio. Journal of Fluids and Structures. 2003. Vol. 17. Pp. 701-715.

15. Wu S.J., Miau J.J., Hu C. C. Chou J.H. On low-frequency modulations and three-dimensionality in vortex shedding behind a normal plate. Journal of Fluid Mechanics. 2005. Vol. 526. Pp. 117-146.

16. Zinoviev V.N., Lebiga V.A., Miau J.J., Chung K.M., Hu C.C. and Tu J.K. Experimental investigation of flow fluctuations around the cylinder in subsonic flows with the help of Hilbert transform and the EMD technique. NSC - RFBR Joint Sympos. "Numerical and Experimental Modeling of Microprocesses and Its Application in Continuum Mechanics ", 28-30 November 2006, Tainan, Taiwan, p. IV-2.

17. Lin Y.J., Miau J.J., Tu J.K. and Tsai H.W. Nonstationary, three-dimensional aspects of flow around circular cylinder at critical Reynolds numbers. AIAA Journal. 2011 Vol. 49. Pp. 1857-1870.

18. Miau J. J., Tsai H. W., Lin Y. J., Tu J. K., Fang C. H. and Chen M. Experiment on smooth circular cylinders in cross-flow in the critical Reynolds number regime. Experiments in Fluids. 2011. Vol. 51. Pp. 949-967.

19. Hasebe H., Watanabe K., Watanabe Y. and Nomura T. Experimental study on the flow field between two square cylinders in tandem arrangement. Proceedings of $7^{\text {th }}$ Asian-Pacific Conference on Wind Engineering. Taipei, Taiwan. 2009. Pp. 631-634,

20. Chang T.C., Lin J.H., Chang K.C., Wang M.R. Investigation of velocity measurement in backward-facing step flow. Proceedings of 2011 Conference of Aeronautical and Astronautical Society of R. O. C. 2011. Paper No.02-15.

21. Li C.T., Chang K.C., and Wang M.R. PIV measurements of turbulent flow in planar mixing layer. Experimental Thermal and Fluid Science. 2009. Vol. 33. Pp. 527-537.

22. Li C. T., Chang K.C., and Wang M. R. Experimental study on evolution of joint velocity PDF in planar mixing layer. Experimental Thermal and Fluid Science. 2010. Vol. 34. Pp. 1122-1132.

23. Miau J. J., Fang C.H., Chen C.M., Yang R.J., Fomin V., Lebiga V., Zinovyev V. Discrete transition of flow over a circular cylinder in the pre-critical regime. Taiwan-Russia Bilateral Symposium on Mechanical Engineering. Taiwan, Hsinchu. Nov. 8-9, 2011. Abstract Book. p. 8.

24. Menter F.R. Zonal two equation k-w turbulence models for aerodynamic flows. AIAA Paper. 1993. No.2906. Pp. 1-21.

25. Hellsten A. Some improvements in Menter's k- $\omega$ turbulence model. AIAA Paper. 1998. No.98-2554. 11 p.

26. Smirnov P.E., Menter F. Sensitization of the SST turbulence model to rotation and curvature by applying the Spalart-Shur correction term. Proc. ASME Turbo Expo Conf., 2008. N GT2008-50480. 10 p.

Isaev S.A., Vatin N.I., Lebiga V.A., Zinoviev V.N., Keh-Chin Chang, Jiun-Jih Miau. Problems and methods of numerical and experimental investigation of high rise constructions' aerodynamics in the coastal region "sea-land" 
27. Menter F.R., Kuntz M., Langtry R. Ten years of industrial experience with the SST turbulence model. Proceedings of the Fourth International Symposium on Turbulence, Heat and Mass Transfer, Antalya, Turkey, 12-17 October, 2003. Pp. 625-632.

28. Esch T., Menter F.R. Heat transfer predictions based on two-equation turbulence models with advanced wall treatment. Proceedings of the Fourth International Symposium on Turbulence, Heat and Mass Transfer, Antalya, Turkey, 12-17 October, 2003. Pp. 663-640.

29. Spalart P.R., Allmares S.R. A one-equation turbulence model for aerodynamic flows. AIAA Paper. 1992. No.92-0439. 22 p.

30. Davidson L. Evaluation of the SST-SAS model: channel flow, asymmetric diffuser and axy-symmetric hill. Proc. European Conf on CFD. Eds. P. Wesseling, E. Onate and J. Periaux. TU Delft, The Netherlands. 2006. 20 p.

31. Tkachenko I., Kornev N., Jahnke S., Steffen G., Hassel E. Performances of LES and RANS models for simulation of complex flows in a coaxial jet mixer. Flow Turbulence Combust. 2007. Vol. 78. Pp. 111-127.

32. Van Doormaal J.P., Raithby G.D. Enhancement of the SIMPLE method for predicting incompressible fluid flow. Numer. Heat Transfer. 1984. Vol.7. No. 2. Pp. 147-163.

33. Ferziger J.H., Peric M. Computational methods for fluid dynamics. Berlin: Springer-Verlag, 1999. 389 p.

34. Leonard B.P. A stable and accurate convective modeling procedure based on quadratic upstream interpolation. Comp. Meth. Appl. Mech. Eng. 1979. Vol.19. No.1. Pp. 59-98.

35. Lien F.S., Leschziner M.A. Approximation of turbulence convection in complex flows with a TVD-MUSCL scheme. Proc. $5^{\text {th }}$ Int. Symp. Refined flow modelling and turbulence measurements. Paris, 1993. Pp.183190.

36. Oosteriee C.W., Gaspar F.J., Washio T., Wienands R. Multigrid line smoothers for higher order upwind discretizations of convection-dominated problems. J. Comp. Physics. 1998. No.1. Pp. 274-307.

37. Thompson J.F. Numerical solution of flow problems using body-fitted coordinate systems. Computational Fluid Dynamics. 1980. Vol. 1. Pp. 1-98.

Full text of this article in English: pp. 54-61

Isaev S.A., Vatin N.I., Lebiga V.A., Zinoviev V.N., Keh-Chin Chang, Jiun-Jih Miau. Problems and methods of numerical and experimental investigation of high rise constructions' aerodynamics in the coastal region "sea-land" 